\title{
Introduced predators and nest competitors shape distribution and breeding performance of seabirds: feral pigeons as a new threat
}

\author{
Beneharo Rodríguez $\mathbb{D} \cdot$ Airam Rodríguez $\mathbb{D} \cdot$ \\ Felipe Siverio • Juan M. Martínez \\ Enrique Sacramento $\cdot$ Yarci Acosta $(\mathbb{D}$
}

Received: 21 May 2021 / Accepted: 27 January 2022 / Published online: 23 February 2022

(C) The Author(s) 2022

\begin{abstract}
Petrels are particularly sensitive to predation by introduced species. Many populations have reduced their breeding ranges, currently mainly occupying predator-free sites. Breeding range reduction leads to interspecific competition for nesting sites, which can be detrimental to petrels. Here, we evaluate how the presence of introduced mammals (cats Felis catus and rats Rattus spp.) and potential competitors for nest sites (Cory's shearwaters Calonectris borealis and feral rock pigeons Columba livia) shape the distribution, breeding density, and breeding performance of Bulwer's petrel Bulweria bulwerii on Tenerife, the largest and most densely human populated of the Canary Islands. We estimated nest density, assessed the role of nest location and physical characteristics of nests on breeding success, and determined
\end{abstract}

Supplementary Information The online version contains supplementary material available at https://doi. org/10.1007/s10530-022-02746-1.

B. Rodríguez $\cdot$ F. Siverio $\cdot$ E. Sacramento Canary Islands' Ornithology and Natural History Group (GOHNIC), Buenavista del Norte, Canary Islands, Spain

B. Rodríguez · J. M. Martínez · Y. Acosta Sociedad Española de Ornitología (SEO/BirdLife), Delegación de Canarias, La Laguna, Canary Islands, Spain

A. Rodríguez ( $\square)$

Terrestrial Ecology Group (TEG-UAM), Department of Ecology, Universidad Autónoma de Madrid, Madrid, Spain

e-mail: airam.rodriguez@uam.es causes of breeding failure by introduced predators and competitors. Nest density was higher in predatorfree colonies on marine rocks. Cat presence was the best predictor of nest density, but it was not correlated with either presence or abundance of competitors. Breeding success varied between years and colonies but was not related to nest characteristics. Pigeon competition for nests was the most frequent cause of breeding failure $(7.3 \%)$, followed by rat predation $(6.3 \%)$. We also compared petrel and pigeon nest cavities and found considerable overlap in the physical size of nest sites. Our study provides insights into an overlooked impact of the invasive rock pigeon: nest competition with small seabirds. We encourage more research on the effects of pigeons on nest density, as well as disease and pathogen transmission, and vegetation changes within seabird colonies.

Keywords Breeding colony - Conservation · Competition $\cdot$ Predation $\cdot$ Procellariiformes $\cdot$ Rock dove $\cdot$ Seabird

\section{Introduction}

Seabirds and, particularly, petrels (order Procellariiformes) occur in vast ocean areas, but their breeding colonies are usually restricted to islands that are markedly limited in area in comparison with their large pelagic feeding grounds (Brooke 2018). The reduced breeding range is thought to be a consequence of 
predation. Predation pressure is generally lower on islands than on the mainland, although humans have introduced many predators worldwide (Mulder et al. 2011). Petrels are in decline mainly due to predation by introduced species on their breeding grounds, being one of the most endangered avian groups (Rodríguez et al. 2019; Dias et al. 2019). So, invasive species drive petrel local extinctions and restrict breeding petrel distribution to predator-free sites, such as islets or sea cliffs (Spatz et al. 2014, 2017).

The breeding density of birds is usually limited by the availability of nesting sites and, for cavity-nesting bird species, cavities are a limited resource (Newton 1994). Many seabirds, especially petrels, nest underground, and share nesting grounds with other species. Under these circumstances, sympatric species fiercely compete for favourable nesting sites, with the smaller species usually defeated (Cory's shearwater Calonectris borealis vs. Bulwer's petrel Bulweria bulwerii, Macaronesian shearwater Puffinus baroli, and band-rumped storm-petrel Hydrobates castro; Ramos et al. 1997; Wedge-tailed shearwater Ardenna pacifica vs. Tahiti petrel Pseudobulweria rostrata; Villard et al. 2006; Streaked shearwater Calonectris leucomelas vs. H. castro and Swinhoe's storm-petrel Hydrobates monorhis; Sato et al. 2010; Bonin petrel Pterodroma hypoleuca and A. pacifica vs. Tristam's storm-petrel Hydrobates tristami; McClelland et al. 2008), although differences in microhabitat or nest site characteristics can partially alleviate interspecific competition (Sullivan and Wilson 2001; Bourgeois and Vidal 2007; Troy et al. 2016).

Our knowledge on interspecific interactions between petrels and other non-petrel native species is limited. Evidence suggests that competition for nesting holes has little effect on petrels under natural conditions, i.e. without cumulative effects of other anthropogenic threats (Rodríguez et al. 2019). However, when native species abundance increases as a result of human actions, such as provision of supplementary food or nesting habitat, interspecific competition can be detrimental for threatened petrel populations, e.g. the nest competition of white-tailed tropicbird Phaethon lepturus hampered the recovery of the endangered Bermuda petrel Pterodroma cahow (Madeiros et al. 2012). Future research on interspecific interactions must be further intensified and focused on identifying problematic species for endangered petrels, because this basic information is still unavailable for many of them (Rodríguez et al. 2019).

In the Canary Islands, seven procellariiform species breed currently (Bulwer's petrel B. bulwerii, Cory's shearwater $C$. borealis, Manx shearwater Puffinus puffinus, Macaronesian shearwater $P$. baroli, European storm-petrel Hydrobates pelagicus, band-rumped storm-petrel $H$. castro and white-faced storm-petrel Pelagrodroma marina). All of them are threatened with declining small populations, except Cory's shearwater (Lorenzo 2007). Small-sized species show small and patchily distributed breeding colonies, mainly located on predator-free islets and marine rocks which are difficult to access (Lorenzo 2007). Due to the limited surface of these breeding areas, competition between birds for nest sites may be intense as in other nearby locations (Ramos et al. 1997; Bried and Bourgeois 2005).

The rock pigeon Columba livia is an invasive species introduced worldwide (CABI 2008), which has been eradicated from the Galápagos Islands to protect its unique biodiversity applying the "precautionary principle" (Phillips et al. 2012). This species, native to Europe and the Canary Islands (geographically closer to Africa than mainland Europe), has suffered a genetic introgression with domestic pigeons during the last few centuries (Johnston and Janiga 1995; Lorenzo 2007; Giunchi et al. 2020). Thanks to its high reproductive rates and behavioural plasticity, feral rock pigeons can become pests (Johnston and Janiga 1995). The negative ecological impacts of feral rock pigeon populations include transmission of infectious diseases and pathogens (Foronda et al. 2004; Burt et al. 2018; Mori et al. 2019), changes in chemical soil properties by means of the acidity of its excrement (Spennemann and Watson 2017), and competition with native species for resources such as food or nesting sites (Forero et al. 1996; Hernández-Brito et al. 2014). Despite its impacts, field studies focusing on their role as nest competitors are few (e.g. Forero et al. 1996; Hernández-Brito et al. 2014; this study).

Here, we assess the role of feral rock pigeons on the nesting density and breeding performance of a small seabird, Bulwer's petrel, on a densely humanpopulated island of the Canary Islands. To compare the impact of pigeons with that of introduced predators and other nest competitors, we also evaluated the presence of cats Felis catus and rats Rattus spp., and the abundance of native Cory's shearwaters. 
During 2017-2020, we (1) estimated Bulwer's petrel nest density in colonies, (2) assessed the impact of nest location and physical characteristics of nests on breeding success, and (3) quantified causes of breeding failure as a result of introduced predators and native competitors. We hypothesized that at sites where invasive species occur, i.e. cats and rats, nest density and breeding success would be lower than at sites free of introduced predators. Given that the potential nest competitors studied here, i.e. pigeons and shearwaters, are benefited by the absence of introduced predators, i.e. cats and rats, we hypothesized that nest competition could lead to breeding failure at predator-free sites. We also compared physical characteristics of nest cavities used by petrels and pigeons to assess nesting niche segregation. We predict that some overlap occurs between the nesting niches of these two species.

\section{Materials and methods}

\section{Study area and species}

The study was conducted on Tenerife, the largest and the highest $\left(2034 \mathrm{~km}^{2}\right.$ and $3718 \mathrm{~m}$ above sea level-a.s.1.) of the Canary Islands (Fig. S1). The coastline $(342 \mathrm{~km})$ is predominantly rocky with boulder shores, cliffs up to $400 \mathrm{~m}$ high, and small marine rocks on the north coast. The climate is subtropical and oceanic. Oceanographic conditions in this archipelago are influenced by northeast trade winds and marine upwelling that occurs off the north-west African coast. In 2019, the local human population was approximately 949,000 inhabitants, but as the island's economy is highly dependent upon the tourism, each year several millions of visitors are received (Instituto Canario de Estadística, www.gobiernodecanarias.org/ istac/).

Bulwer's petrel is a small pelagic procellariiform (75-130 g), with a disjointed pan-oceanic distribution in tropical and subtropical waters of the Pacific, Indian, and Atlantic Oceans. Canarian Bulwer's petrels visit breeding grounds from April to September and nest mainly in small crevices, caves, and holes under rocks, usually close to the sea, where they lay a single egg per breeding attempt in late May-early June (Hernández et al. 1990; Martín and Lorenzo
2001). Chicks fledge mainly during the second fortnight of September (Martín and Lorenzo 2001).

Cory's shearwater is the largest (700-800 g) and most abundant procellariiform species in the Canary Islands (Lorenzo 2007). It is distributed extensively on the island under $1000 \mathrm{~m}$ a.s.l. and is well known to compete for nests with Bulwer's petrels on other nearby colonies (Ramos et al. 1997; Bried and Bourgeois 2005). Cory's shearwaters visit their breeding colonies from March to November. Single-egg clutches are laid in early June and chicks fledge from late October to early November (Martín and Lorenzo 2001).

In the Canaries, the feral rock pigeon is abundant and distributed widely in rural and urban environments, but especially in coastal sectors (Lorenzo 2007). This sedentary and medium-sized bird (230-370 g) uses holes and crevices on sea cliffs and marine rocks as roosting and breeding sites (Lorenzo 2007). Rock pigeon clutch size is 1-2 eggs and pairs can make several breeding attempts per breeding season. Its breeding period is concentrated in spring and summer, but pigeons can breed throughout the year (Martín and Lorenzo 2001). Nowadays in Tenerife, most rock pigeons seen in the wild resemble birds of domestic origin (authors' pers. obs.). Studies conducted on Tenerife indicate that feral rock pigeons could be vectors of pathogens for the endemic pigeons, Bolle's pigeon Columba bollii and the whitetailed laurel pigeon Columba junoniae (Foronda et al. 2004; Abreu-Acosta et al. 2009).

Two species of rats (black rat Rattus rattus and brown rat $R$. norvegicus) and feral domestic cats Felis catus have been introduced in Tenerife since fifteenth century (Nogales et al. 2006). Rats and cats are widely distributed on the main island, but they are absent on the marine rocks (Nogales et al. 2006; authors' pers. obs.). Introduced mammals intensively depredate eggs, chicks, and adults, which lead to seabird population declines worldwide (Spatz et al. 2017).

Nesting density, nest characteristics and breeding performance

During the 2017-2020 breeding seasons (June-early September), we visited all known Bulwer's petrel nesting sites (Hernández et al. 1990; Lorenzo 2007). Other sites with the potential to accommodate 
colonies (apparently free of introduced predators and with suitable holes) were also visited. We visited 43 sites, spending a total of $218 \mathrm{~h} /$ observer of effective prospection (Fig. S1; Table S1). During daylight hours, we counted the number of Bulwer's petrel and Cory's shearwater nests in places accessible on foot using a hand-held flashlight to inspect holes and crevices. We also recorded the presence or absence of feral rock pigeons, rats, and feral cats according to field signs (individuals, feathers, nests, prey remains, or droppings). Studied site edges, including those without petrels, were delineated and plotted using landscape features in aerial photographs, maps, and a geographic information system (Qgis v3.14.16). Four inaccessible sites were inspected using a thermal monocular Helion XP50 (Pulsar, Lithuania) from vantage points $(80-130 \mathrm{~m})$ to estimate the number of nests according to attendance behaviour of adults. Bulwer's petrel and feral rock pigeon nests from five petrel colonies were described with nine variables (Table 1).

We assessed breeding success of 209 breeding attempts $(2018, n=71 ; 2019, n=70 ; 2020, n=68)$ in five colonies, four of them located on marine rocks (without introduced predators) and one on a coastal cliff (Fig. S1). Each nest was visited at least twice: to confirm incubation in late June or early July and to record the presence or absence of a full-grown chick in late August or early September. We assumed that nestlings observed during the second visit would fledge successfully.

To identify causes of breeding failure, the nest and its surroundings were inspected, paying special attention to the presence of unhatched eggs, eggshells, dead chicks, droppings, and signs of introduced predators. Pigeon nests at sites (e.g. crevices, caves, holes, or burrows) previously used by petrels for nesting, i.e. in the previous breeding season or early in the same breeding season, were considered breeding failures.

\section{Statistical analysis}

To assess the role of the colony location (main island vs. marine rock), presence of predators (cats and rats), and nest competitors (pigeons and Cory's shearwaters) on the density of Bulwer's petrel nests, we ran Linear Models (LMs). We did not include year as a response variable as nest density is relatively consistent among years and we had just a density estimate to many colonies. Given our limited sample size (43 sites), we compared LMs including just a single predictor. Then, we ranked the models according to its AICc value (the lower AICc, the better the model), including a null model containing just the intercept.

To test for potential differences in breeding success ( $0=$ failure; $1=$ success $)$ among colonies and years, we ran Generalized Linear Mixed Models (GLMMs) with family binomial (link $=$ logit). We included nest identity as a random factor, given that the same nests were studied each breeding season, and year and colony as predictors. We ranked competitive models according to AICc.

To assess potential relationships between breeding success $(0=$ failure; $1=$ success $)$ and nest features, we ran GLMMs with family binomial (link = logit). We included nest identity as a random factor and used seven variables describing nests (height, width, depth, chamber height, vertical difference height,
Table 1 Variables used to describe nests of Bulwer's petrels Bulweria bulwerii and feral rock pigeons Columba livia on Tenerife, Canary Islands

\begin{tabular}{ll}
\hline Variable & Description \\
\hline Nest type & $\begin{array}{l}\text { Proportion of nest cavity sides bounded by rock: all rock, rock crev- } \\
\text { ice; soil bed, soil crevice; and all soil, burrow } \\
\text { Minimum height of the nest entrance }(\mathrm{cm})\end{array}$ \\
$\begin{array}{l}\text { Entrance height } \\
\text { Entrance width }\end{array}$ & $\begin{array}{l}\text { Minimum width of the nest entrance }(\mathrm{cm}) \\
\text { Depth }\end{array}$ \\
Chamber height & Height of the nesting chamber $(\mathrm{cm})$ \\
$\begin{array}{l}\text { Difference in heights } \\
\text { Entrance curvature }\end{array}$ & $\begin{array}{l}\text { Difference in height from the entrance and the nesting chamber }(\mathrm{cm}) \\
\text { Slope }\end{array}$ \\
$\begin{array}{l}\text { In degrees }\left(0-90^{\circ}\right), \text { curve between the entrance and the chamber } \\
\text { In degrees }\left(0-180^{\circ}\right), \text { angle measured in a } 1 \mathrm{~m} \text { radii from the nest } \\
\text { entrance considering vertical up as } 0^{\circ}\end{array}$ \\
\hline
\end{tabular}


curved, and slope; see Table 1 for further details) as predictors in univariate models. We ran all competing GLMMs including just a single factor or variable, as well as the null model including just the intercept, to rank them according to the AICc value.

To test for potential differences between the nest sites of petrels and pigeons, we ran permutations tests and plotted the data on the seven continuous variables of Table 1 describing physical characteristics of the nests. In addition, we ran a Principal Component Analysis (PCA) to assess the nesting niche. Variables were zero centered and scaled to have unit variance before the PCA, as they were taken in different scales and units and showed different variance.

Statistical analyses were run in $R$ (v4.0.4). Models were run using the glm.nb and glmer functions of the MASS and lme4 packages. Models were compared to null models using the AICc function (MuMIn package) and assumptions were checked using diagnostic plots. We used the R package coin to conduct the permutation tests and an alpha threshold of 0.05. PCA was conducted by using the prcomp function in the stats package.

\section{Results}

\section{Distribution and nest density}

Most nests (86\%) were on marine rocks off the north coast of the island where they were at the highest density (Table S1; Fig. 1). Nest density was higher in colonies without predators like cats or rats, but it was not related to nest competitors such as feral rock pigeons or Cory's shearwaters (Fig. 2). The linear models indicated that the presence of cats and rats, and colony location (mainland island $v s$. marine rocks) were the best predictors of nest density (Table 2; Estimates \pm S.E. and 95\% CIs: Presence of cats $=-6.93 \pm$ 2.91 [ $-12.81,-1.04]$; Presence of rats $=-6.83 \pm$ $2.99[-12.88,-0.79]$; Marine rocks $=6.36 \pm 2.99$ $[0.33,12.40]$.

Breeding success and causes of breeding failure

Breeding success varied among colonies and years (Table 2 and Table S2). According to the AICc values of the competitive models, the model containing

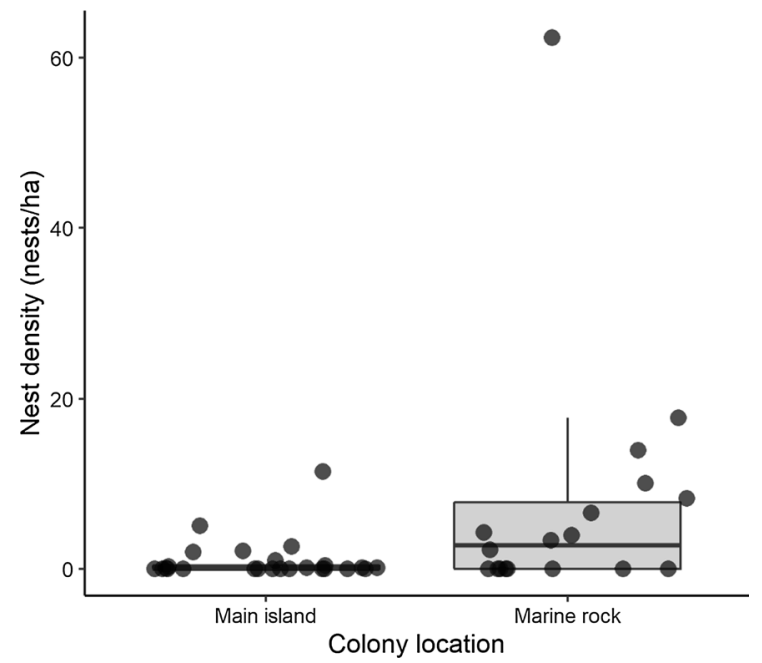

Fig. 1 Box-and-whisker plots of the nesting density of Bulwer's petrels Bulweria bulwerii on the main island and on marine rocks of Tenerife, Canary Islands. Dots have been jittered for a better visualization. The line within boxes indicates the median, the bottom and top of the box represent the first and third quartiles, and the whiskers extend 1.5 times the interquartile range

colony and year as predictors obtained the lowest AICc value (Table 2; see estimates \pm S.E. and 95\% CIs for simple terms in Table S3). The colony located on the main island had the lowest breeding success, where no chicks fledged in 2019 and 2020 breeding seasons (Table S2). According to the GLMMs explaining the breeding success in relation to physical characteristics of nests, any of our studied nest variables were related to breeding success (Table 2). The null model obtained the lowest AICc value (Table 2).

Breeding failure was hard to determine on the ground. Thus, the cause of breeding failure in most breeding attempts was unknown $(75.0 \%)$. At least seven breeding attempts (7.3\%) failed due to Bulwer's petrels being out-competed by feral rock pigeons for nest cavities. Such breeding failure was confirmed in three colonies on marine rocks (Garachico and both of San Juan de La Rambla; \#22, 28, and 29 in Table S1). At least $6.3 \%$ of the breeding attempts failed due to rat predation, all of them located on Los Pedrones on the main island (\#14 in Table S1), although most of failed breeding attempts may have been caused by predation (Table 3 ). 
Fig. 2 Box-and-whisker plots of the nesting density of Bulwer's petrels Bulweria bulwerii according to the presence of introduced predators (cats Felis catus and rats Rattus sp.) and competitors (feral rock pigeons Columba livia and Cory's shearwaters Calonectris borealis) on Tenerife, Canary Islands. Dots have been jittered for a better visualization. The line within boxes indicates the median, the bottom and top of the box represent the first and third quartiles, and the whiskers extend 1.5 times the interquartile range
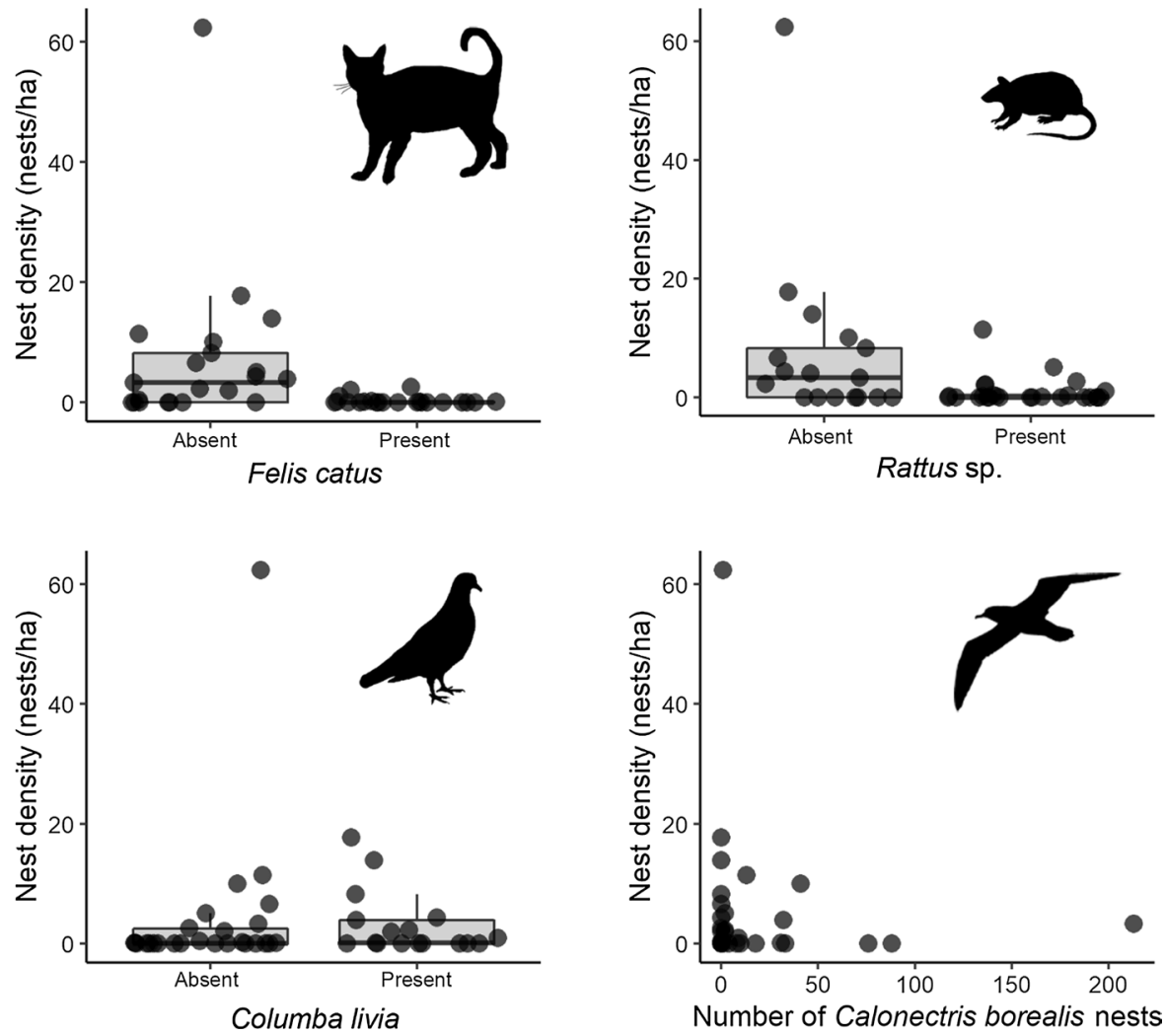

Bulwer's petrel and feral rock pigeon nest characteristics

A considerable overlap in features describing Bulwer's petrel and pigeon nests was observed according to the Principal Component Analysis, indicating both species share part of their nesting niches (Fig. 3; Table S4). PC1 retained $33.5 \%$ of the variation and was highly correlated with entrance height $(-0.89)$, chamber height $(-0.74)$, depth $(-0.65)$, and entrance width (-0.54). PC2 retained $16 \%$ of the variation and was highly correlated with difference in heights $(-0.71)$, entrance curvature $(-0.52)$, and entrance width $(-0.51)$ (Table S4). Five out of the seven variables describing the petrel and pigeon nests reached significant differences (Table S5, Fig. S2). Petrel nests had smaller entrances (i.e. lower height and width) and smaller nesting chambers (i.e. height). Petrel nest entrances were more curved than those of pigeon nests, and slopes were steeper in pigeon nests. Depth and vertical difference in height between entrance and nest chambers were similar in the two species' nests (Table S5, Fig. S2).

\section{Discussion}

Our results support our hypotheses and indicate that the main factor shaping breeding distribution of small procellariiforms, such as Bulwer's petrel, is the presence of invasive mammals (Spatz et al. 2014, 2017). In addition, nest competition with feral rock pigeons was the main identified cause of breeding failure of Bulwer's petrels, highlighting an overlooked impact of this species (which can become a pest or invasive species depending on its native or introduced range) on small seabirds. This was supported by the overlap in the nesting niches of both species. Contrary to our predictions, our data do not provide any evidence for impacts of Cory's shearwaters on Bulwer's petrel nesting density or breeding success.

Rats and cats have been present in the Canary Islands for several centuries (Nogales et al. 2006). So, these predators have shaped the current breeding distribution of Bulwer's petrels, mainly relegating them to isolated predator-free marine rocks on which dense colonies form (Hernández et al. 1990). At predator-free sites, such as the Desertas Islands, 
Table 2 Results of the LMs and GLMMs explaining nest density and breeding success of Bulwer's petrel Bulweria bulwerii on Tenerife, Canary Islands, during 2018-2020 breeding seasons. See main text for details

\begin{tabular}{|c|c|c|c|}
\hline Predictor & df & $\mathrm{AICc}$ & $\Delta \mathrm{AICc}$ \\
\hline \multicolumn{4}{|l|}{ Nest density } \\
\hline Presence of Felis catus & 3 & 320.66 & 0.00 \\
\hline Presence of Rattus sp. & 3 & 321.06 & 0.40 \\
\hline $\begin{array}{l}\text { Colony location (main island or marine } \\
\text { rock) }\end{array}$ & 3 & 321.70 & 1.04 \\
\hline Null model & 2 & 323.89 & 3.24 \\
\hline Presence of Columba livia & 3 & 326.13 & 5.47 \\
\hline Abundance of Calonectris borealis & 3 & 326.13 & 5.47 \\
\hline \multicolumn{4}{|l|}{ Breeding success vs. colony and year } \\
\hline Colony * Year & 16 & 279.33 & 0 \\
\hline Colony + Year & 8 & 280.98 & 1.65 \\
\hline Colony & 6 & 281.81 & 2.48 \\
\hline Null model & 2 & 285.46 & 6.13 \\
\hline Year & 4 & 285.74 & 6.41 \\
\hline \multicolumn{4}{|l|}{ Breeding success vs. nest traits } \\
\hline Null model & 2 & 285.46 & 0 \\
\hline Difference in heights & 3 & 286.21 & 0.75 \\
\hline Chamber height & 3 & 286.87 & 1.41 \\
\hline Slope & 3 & 287.07 & 1.61 \\
\hline Entrance curvature & 3 & 287.19 & 1.73 \\
\hline Entrance height & 3 & 287.43 & 1.97 \\
\hline Entrance width & 3 & 287.51 & 2.05 \\
\hline Depth & 3 & 287.51 & 2.05 \\
\hline
\end{tabular}

Table 3 Causes of breeding failure of Bulwer's petrel Bulweria bulwerii breeding attempts on Tenerife, Canary Islands, during 2018-2020 breeding seasons

\begin{tabular}{ll}
\hline Causes of breeding failure $(n=96)$ & $n(\%)$ \\
\hline Unknown & $72(75.0)$ \\
Nest competition with pigeons & $7(7.3)$ \\
Predation by rats & $6(6.3)$ \\
Abandoned egg & $4(4.2)$ \\
Dead chick & $4(4.2)$ \\
Broken egg & $2(2.1)$ \\
Chick falling from nest site & $1(1.0)$ \\
\hline
\end{tabular}

Madeira, breeding success ranges between 60 and 75\% (Nunes and Vicente 1998), but in rat-invaded colonies on the Bonin Islands, Japan, marked die-off of breeding adults by predation can occur (Kawakami et al. 2010). As a whole, breeding success in Tenerife

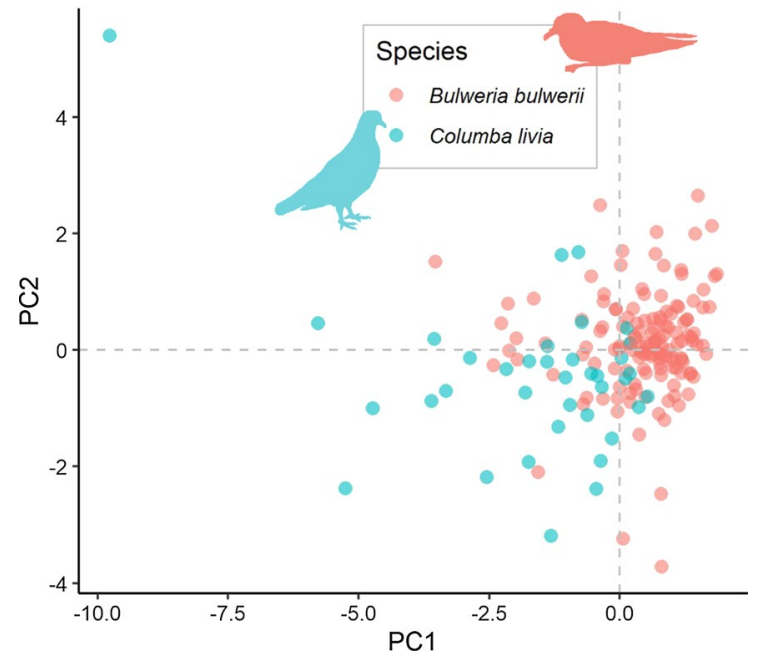

Fig. 3 Scores on the second principal component axis (PC2) plotted against those on the first principal component axis (PC1) from a PCA carried out on seven continuous variables describing Bulwer's petrel Bulweria bulwerii (red) and feral rock pigeon Columba livia (blue) nests on Tenerife, Canary Islands, during 2018-2020 breeding seasons

is low (54.1\% of laid eggs produced a fledgling), but we observed strong spatiotemporal variation. No fledglings were produced during two consecutive seasons on a coastal locality on the main island (\#14 in Table S1) where invasive rats were present. By contrast, in the predator-free sites more than $50 \%$ of the breeding attempts produced a fledgling (Table S2).

Nest competition with feral rock pigeons was the main identified cause of breeding failure of Bulwer's petrels. A minimum of 7.3\% of Bulwer's petrel breeding attempts failed due to interactions with pigeons. In those cases, we confirmed that pigeons occupied petrel nests causing breeding failure (signified by the presence of unattended eggs or dead chicks) or disruption to the petrel's use of the nest sites. Similar to small petrels, feral rock pigeons also benefit from nesting and roosting on predator-free marine rocks to avoid predation (authors' pers. obs.). Other agonistic interactions may occur between nesting or roosting pigeons and breeding petrels. Aggressive interactions might disrupt petrel nest attendance and transmit pathogens and diseases, leading finally to petrel breeding failure (Forero et al. 1996; Foronda et al. 2004; Hernández-Brito et al. 2014).

Although we failed to detect a clear relationship between petrel nest density and pigeon competition, 
systematic breeding failure mediated by pigeon competition for nest sites might deflate petrel nesting density to a point of local extinction. Field observations support this reasoning. First, the highest nesting density of petrels was recorded on the small rock La Coronela (\#25 in Table S1), where no feral rock pigeons were present. Second, on Roque La Playa (\#33 in Table S1), we found only six petrel nests in the same area where a minimum of 18 nests were counted in August-September 1983 (E. Hernández, com. pers.). Furthermore, we confirmed the presence of seven pigeon nests, three of them at sites previously used by petrels (E. Hernández, com. pers.). Third, we could not detect petrels on two predator-free rocks representing a potentially large extension to apparent suitable nesting habitat (\#30 and \#31 in Table S1). These rocks held at least four Cory's shearwater breeding pairs and a large number of breeding and roosting pigeons ( $>110$ pigeons counted at dusk). Unfortunately, no previous estimates of petrel abundance were available for these rocks. A plausible explanation for the absence of petrels is the interspecific competition with increasing number of pigeons. In support, qualitative comparisons between old and current photographs show marked loss of vegetation in recent decades. The Canary spurge Euphorbia canariensis population has declined from nine large plants to only one small plant (Fig. S3), which is probably related to the acidity and accumulation of pigeon excrement (Spennemann and Watson 2017; Fig. S4).

Pigeon population size increases primarily around human-modified areas (e.g. livestock farms, cereal silos, garbage dumps, dunghills, and urban centres) (Giunchi et al. 2012). Therefore, petrel breeding colonies closer to these sites are more susceptible to pigeon nest competition. At a global scale, the breeding distribution of Bulwer's petrels, but also other endangered small petrel species, greatly overlaps with the range of native and introduced pigeons. Therefore, nest competition between them may occur, particularly in proximity to human-transformed landscapes. Despite the information gap on nest competition nest between feral rock pigeons and seabirds in scientific journals, our results are not the only evidence. We have compiled evidence of pigeon nest competition with at least 15 species across the world (Table 4). More studies are required to understand in greater detail the role of pigeons on seabird nest density, transmission of diseases and pathogens to seabirds, and vegetation changes at seabird colonies.

\section{Conservation implications}

The Canarian Bulwer's petrel faces several humanrelated threats on land, i.e. predation by introduced mammal predators (Hernández et al. 1990), collisions with electricity transmission wires (GómezCatasús et al. 2021), road casualties (Tejera et al. 2018), habitat destruction and attraction to artificial night lights (Rodríguez et al. 2012). These threats mainly occur on the main human-inhabited islands. Owing to this fact, the bulk of the breeding pairs are currently restricted to geographically small secure breeding sites (mostly marine rocks). We highlight an overlooked threat to these petrel sanctuaries: pigeon competition for nesting sites. To minimize such interspecific competition as a matter of urgency, artificial nest boxes should be installed in the main petrel sanctuaries (marine rocks) with high densities of pigeons. Artificial nests must be designed to exclude pigeons and larger Procellariiformes, i.e. Cory's shearwater, by designing them with long and narrow entrances. This action would facilitate long-term monitoring of population and breeding success, and would help to improve the conservation status of Bulwer's petrel by providing secure nest sites. This action has successfully increased the annual productivity of other endangered petrel species (Bolton et al. 2004). Given that rock pigeons can easily become a pest (CABI 2008), we also advocate their culling in some petrel colonies to avoid unnatural high densities (Giunchi et al. 2012). Of course, other small petrels (e.g. Macaronesian shearwater Puffinus baroli and bandrumped storm-petrel Hydrobates castro) and endemic species (i.e. land snails, lizards and plants) living in those marine rocks might also benefit from feral rock pigeon removal or control. On the main island colonies, control of invasive mammals is the most urgently required intervention, but additional actions to reduce artificial light attraction, and wire and vehicle collisions should be also considered.

Acknowledgements We thank the collaboration and essential help in the field work of Manuel Siverio, José Juan Hernández, David Rodal Santiago "Vilayta", Ángeles Taoro, M. Nazaret Carrasco, Aurelio J. Acevedo, and David P. Padilla. We accessed some dangerous and steep marine rocks thanks to Javier Martín Carbajal and Raúl Martínez. Thanks to the 


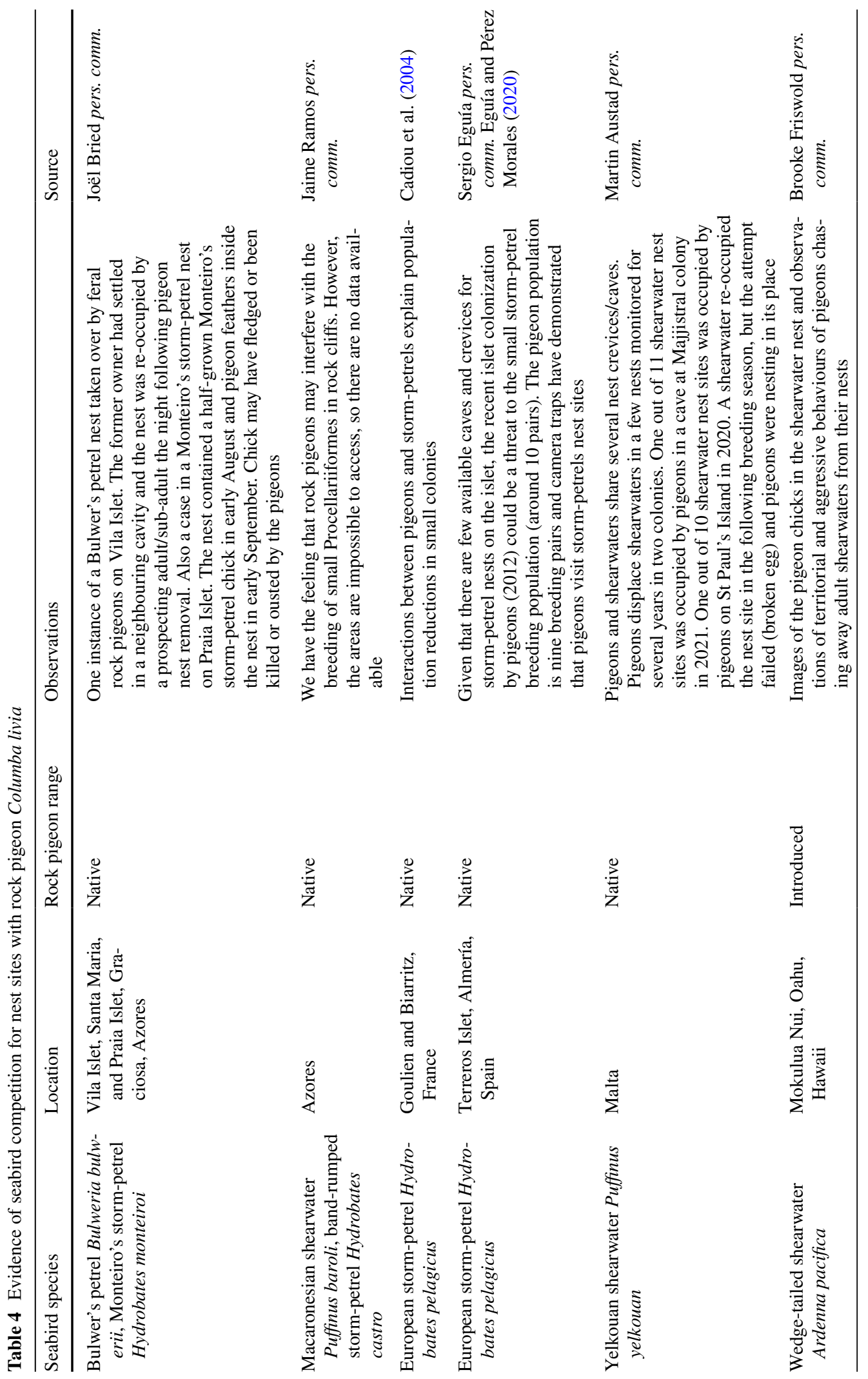




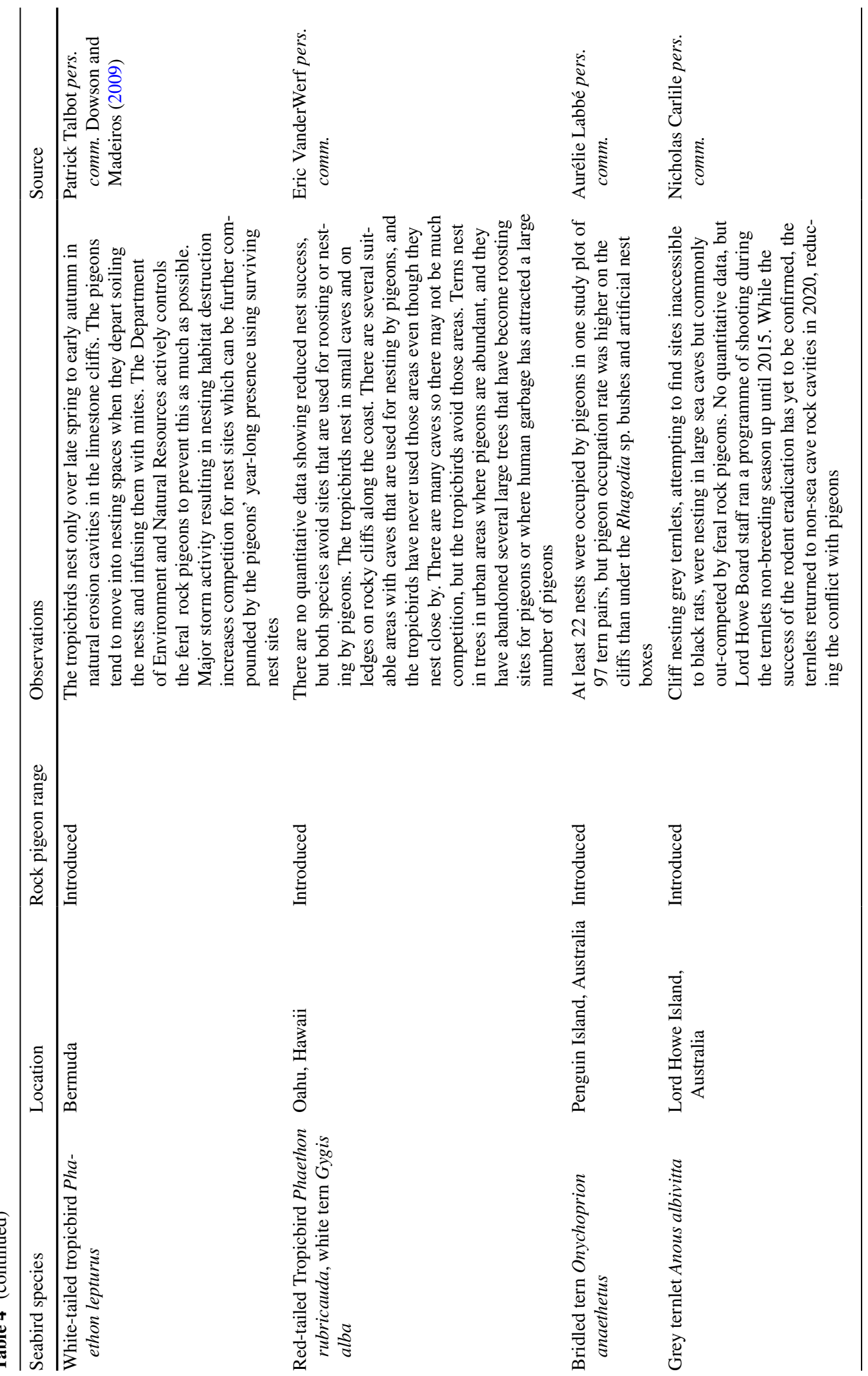


skills of Iván Méndez, Juan Curbelo, Moisés de León, Héctor Manuel Figueroa, Adrián Borges, José María Benítez, and Eligio Benítez as skippers, we landed in all rocks and inaccessible coastal sectors. This study was coordinated by the Canarian regional SEO/BirdLife's office. Our special thanks to its staff, Juan Antonio Lorenzo and Elena Ramos. We thank Chloe Carothers-Liske for improving the English grammar. We also thank Benjamin Metzger and James Crymble of BirdLife Malta and those colleagues included in Table 4 for sharing their observations on nesting competition between seabirds and pigeons. Two anonymous reviewers improved an earlier version.

Author contributions $\mathrm{BR}$ and AR designed the study. BR, FS, JMM, ES, and AR collected field data. AR analyzed the data. YA managed and coordinated the research project. BR and AR drafted the manuscript and all authors commented and approved the final version of the manuscript.

Funding Open Access funding provided thanks to the CRUE-CSIC agreement with Springer Nature. This study was funded by the project INTERREG MAC/4.6d/157 LuMinAves.

Data availability All data are included in the article and its supplementary information files.

\section{Declarations}

Conflict of interest The authors declare that they have no conflict of interest.

Ethical approval All procedures in this study were approved by insular and regional governments. Permits to conduct fieldwork were granted by Cabildo de Tenerife (Permit Numbers: AFF82/17, AFF94/18, and AFF142/19) and Gobierno de Canarias (permit numbers: 2017/10464 and 2018/6842).

Open Access This article is licensed under a Creative Commons Attribution 4.0 International License, which permits use, sharing, adaptation, distribution and reproduction in any medium or format, as long as you give appropriate credit to the original author(s) and the source, provide a link to the Creative Commons licence, and indicate if changes were made. The images or other third party material in this article are included in the article's Creative Commons licence, unless indicated otherwise in a credit line to the material. If material is not included in the article's Creative Commons licence and your intended use is not permitted by statutory regulation or exceeds the permitted use, you will need to obtain permission directly from the copyright holder. To view a copy of this licence, visit http://creativecommons.org/licenses/by/4.0/.

\section{References}

Abreu-Acosta N, Foronda-Rodriguez P, Lopez M, Valladares B (2009) Ocurrence of Cryptosporidium hominis in pigeons 
(Columba livia). Acta Parasitol 54:1-5. https://doi.org/10. 2478/s11686-009-0008-4

Bolton M, Medeiros R, Hothersall B, Campos A (2004) The use of artificial breeding chambers as a conservation measure for cavity-nesting procellariiform seabirds: a case study of the Madeiran storm petrel (Oceanodroma castro). Biol Conserv 116:73-80. https://doi.org/10.1016/ S0006-3207(03)00178-2

Bourgeois K, Vidal É (2007) Yelkouan shearwater nest-cavity selection and breeding success. Comptes Rendus Biol 330:205-214. https://doi.org/10.1016/j.crvi.2006.12.007

Bried J, Bourgeois K (2005) Which future for Bulwer's Petrel in the Azores? Airo 15:51-55

Brooke M (2018) Far from land: the mysterious lives of seabirds. Princeton University Press, Princeton

Burt SA, Röring RE, Heijne M (2018) Chlamydia psittaci and C. avium in feral pigeon (Columba livia domestica) droppings in two cities in the Netherlands. Vet Q 38:63-66. https://doi.org/10.1080/01652176.2018.1482028

CABI (2008) Invasive species compendium: Columba livia (pigeons). In: Cent. Agric. Biosci. Int. https://www.cabi. org/isc/datasheet/87913/. Accessed 17 Dec 2021

Cadiou B, Pons J-M, Yésou P (2004) Oiseaux marins nicheurs de France métropolitaine (1960-2000). Éditions Biotope, Mèze, France

Dias MP, Martin R, Pearmain EJ et al (2019) Threats to seabirds: a global assessment. Biol Conserv 237:525-537. https://doi.org/10.1016/j.biocon.2019.06.033

Dowson AF, Madeiros J (2009) Threats facing Bermuda's breeding seabirds: measures to assist future breeding success. In: Proceedings of the fourth international partners in flight conference: tundra to tropics. Partners in flight, pp 223-226

Eguía S, Pérez Morales A (2020) Informe sobre los trabajos de seguimiento de la población de paíño europeo Hydrobates pelagicus de la Isla de Terreros, 2020. PESCAVIVA REAL S.L.U

Forero MG, Tella JL, Donfizar JA, Hiraldo F (1996) Can interspecific competition and nest site availability explain the decrease of Lesser Kestrel Falco naumanni populations? Biol Conserv 78:289-293

Foronda P, Valladares B, Rivera-Medina JA et al (2004) Parasites of Columba livia (Aves: Columbiformes) in Tenerife (Canary Islands) and their role in the conservation biology of the Laurel pigeons. Parasite 11:311-316

Giunchi D, Albores-barajas YV, Baldaccini NE et al (2012) Feral pigeons: problems, dynamics and control methods. In: Larramendy ML, Soloneski $\mathrm{S}$ et al (eds) Integrated pest management and pest control: current and future tactics. InTech, Rijeka, pp 215-240

Giunchi D, Mucci N, Bigi D et al (2020) Feral pigeon populations: their gene pool and links with local domestic breeds. Zoology 142:125817. https://doi.org/10.1016/j. zool.2020.125817

Gómez-Catasús J, Carrascal LM, Moraleda V et al (2021) Factors affecting differential underestimates of bird collision fatalities at electric lines: a case study in the Canary Islands. Ardeola 68:71-94. https://doi.org/10.13157/arla. 68.1.2021.ra5

Hernández-Brito D, Carrete M, Popa-Lisseanu AG et al (2014) Crowding in the city: losing and winning competitors of an invasive bird. PLoS ONE 9:e100593. https://doi.org/ 10.1371/journal.pone.0100593

Hernández E, Martín A, Nogales M et al (1990) Distribution and status of Bulwer's Petrel (Bulweria bulwerii Jardine $\&$ Selby, 1828) in the Canary Islands. Bol do Mus Munic do Funchal 47(214):5-16

Johnston RF, Janiga M (1995) The feral pigeons. Oxford University Press, London

Kawakami K, Horikoshi K, Suzuki H, Sasaki T (2010) Impacts of predation by the invasive Black Rat Rattus rattus on the Bulwer's Petrel Bulweria bulwerii in the Bonin Islands, Japan. In: Restoring the Oceanic Island Ecosystem. Springer Japan, Tokyo, pp 51-55

Lorenzo JA (2007) Atlas de las aves nidificantes en el archipiélago canario 1997-2003. Dirección General de Conservación de la Naturaleza-SEO/BirdLife, Madrid

Madeiros J, Carlile N, Priddel D (2012) Breeding biology and population increase of the Endangered Bermuda Petrel Pterodroma cahow. Bird Conserv Int 22:35-45. https://doi.org/10.1017/S0959270911000396

Martín A, Lorenzo JA (2001) Aves del archipiélago canario. Francisco Lemus, La Laguna

McClelland GTW, Jones IL, Lavers JL, Sato F (2008) Breeding biology of Tristram's Storm-petrel Oceanodroma tristrami at French Frigate Shoals and Laysan Island, Northwest Hawaiian Islands. Mar Ornithol 36:175-181

Mori E, Sala JP, Fattorini N et al (2019) Ectoparasite sharing among native and invasive birds in a metropolitan area. Parasitol Res 118:399-409. https://doi.org/10.1007/ s00436-018-6174-2

Mulder CPH, Anderson WB, Towns DR, Bellingham PJ (2011) Seabird Islands: ecology, invasion, and restoration. Oxford University Press, Oxford

Newton I (1994) The role of nest sites in limiting the numbers of hole-nesting birds: a review. Biol Conserv 70:265-276

Nogales M, Rodríguez-Luengo JL, Marrero P (2006) Ecological effects and distribution of invasive non-native mammals on the Canary Islands. Mamm Rev 36:49-65. https:// doi.org/10.1111/j.1365-2907.2006.00077.x

Nunes M, Vicente L (1998) Breeding cycle and nestling growth of Bulwer's Petrel on the Desertas Islands, Portugal. Waterbirds 21:198-204

Phillips RB, Cooke BD, Carrión V, Snell HL (2012) Eradication of rock pigeons, Columba livia, from the Galápagos Islands. Biol Conserv 147:264-269. https://doi.org/10. 1016/j.biocon.2012.01.013

Ramos JA, Monteiro LR, Sola E, Moniz Z (1997) Characteristics and competition for nest cavities in burrowing Procellariiformes. Condor 99:634-641. https://doi.org/10.2307/ 1370475

Rodríguez A, Arcos JM, Bretagnolle V et al (2019) Future directions in conservation research on petrels and shearwaters. Front Mar Sci 6:94. https://doi.org/10.3389/fmars. 2019.00094

Rodríguez A, Rodríguez B, Lucas MP (2012) Trends in numbers of petrels attracted to artificial lights suggest population declines in Tenerife, Canary Islands. Ibis (Lond 1859) 154:167-172. https://doi.org/10.1111/j.1474-919X. 2011.01175.x 
Sato F, Karino K, Oshiro A et al (2010) Breeding of Swinhoe's Storm-petrel Oceanodroma monorhis in the Kutsujima Islands, Kyoto, Japan. Mar Ornithol 38:133-136

Spatz DR, Holmes ND, Reguero BG et al (2017) Managing invasive mammals to conserve globally threatened seabirds in a changing climate. Conserv Lett 10:736-747. https://doi.org/10.1111/conl.12373

Spatz DR, Newton KM, Heinz R et al (2014) The biogeography of globally threatened seabirds and island conservation opportunities. Conserv Biol 28:1282-1290. https:// doi.org/10.1111/cobi.12279

Spennemann DHR, Watson MJ (2017) Dietary habits of urban pigeons (Columba livia) and implications of excreta $\mathrm{pH}$ : a review. Eur J Ecol 3:27-41. https://doi.org/10.1515/ eje-2017-0004

Sullivan W, Wilson K-J (2001) Differences in habitat selection between Chatham petrels implications for management of burrow competition. N Z J Ecol 25:65-69
Tejera G, Rodríguez B, Armas C, Rodríguez A (2018) Wildlife-vehicle collisions in Lanzarote Biosphere Reserve, Canary Islands. PLoS ONE 13:e0192731. https://doi.org/ 10.1371/journal.pone.0192731

Troy JR, Holmes ND, Joyce T et al (2016) Characteristics associated with Newell's shearwater (Puffinus newelli) and Hawaiian petrel (Pterodroma sandwichensis) burrows on Kauai, Hawaii, USA. Waterbirds 39:199-204. https://doi. org/10.1675/063.039.0211

Villard P, Dano S, Bretagnolle V (2006) Morphometrics and the breeding biology of the Tahiti Petrel Pseudobulweria rostrata. Ibis 148:285-291. https://doi.org/10.1111/j. 1474-919X.2006.00528.x

Publisher's Note Springer Nature remains neutral with regard to jurisdictional claims in published maps and institutional affiliations. 